\title{
Writing is more than 'exciting': equipping primary children to become reflective writers
}

\author{
Roy Corden
}

\begin{abstract}
This article describes work undertaken as part of a partnership programme initiated to encourage collaborative research between teachers and university tutors. In the Teaching Reading and Writing Links project (TRAWL) primary school teachers, working as research partners, explored ways of developing children as reflective writers. The research group wanted to know whether, through examining how texts are crafted by expert writers during literacy sessions, children might be encouraged to pay more attention to compositional rather than secretarial aspects of narrative writing during writing workshops. The overall writing achievement of 338 children was monitored over one school year and narrative writing from 60 case study children was evaluated at the beginning and end of the research period. In this article the impact on achievement is illustrated, some examples of writing are analysed and evidence of development in children's metacognition and confidence as writers is discussed.
\end{abstract}

\section{Introduction}

"I've produced over 90 books. Of them, I'm really pleased with 10 , and I' $m$ really displeased with about 25 - which are exclusively the earlier ones, when I was learning my trade."

(Michael Murpurgo 2001)

In its evaluation of the second year of the National Literacy Strategy Ofsted (2000: 9) confirmed that, improving standards in writing had proved to be challenging and that, 'too much time is spent on pupils practising writing rather than being taught how to improve it'. Research in Scotland (Duffield and Peacock, 1999) found that although teachers gave much attention to stimulating writing activity, less was done to support children as they wrote. Her Majesty's Inspector (HMI 2000) emphasised the need for children to work on extended pieces of writing and for teachers to provide continuous feedback during the drafting process. Myhill (2001) concurs and, after undertaking research for the Qualifications and Curriculum Authority (QCA) argues that pupils would benefit from being given more help in understanding how to improve their writing. In its evaluation of the third year of the National Literacy Strategy, Ofsted (2001:6) reports that attainment in writing still 'lags far behind attainment in reading'. This may be because, as Stainthorp (2002) argues, writing is hard. One able nine-year old child, in the TRAWL project stated that when asked to write a story she was in agony. This was a sentiment shared by many pupils who felt anxious, uncertain and simply not equipped to compose an extended written text. When someone as proficient as award winning writer, David Almond (2001), confesses that 'being asked to write a story is terrifying' it is hardly surprising to find primary children in need of support

\section{The Teaching Reading and Writing Links (TRAWL) research project}

Explicit teaching, during focused literacy sessions coupled with opportunities for children to work independently on sustained pieces of narrative writing was the approach used in the TRAWL project. Teachers were keen to develop an approach to writing where they could interact with children and offer support during composition. They hoped that raising awareness of how texts are crafted might encourage children to pay more attention to structural and stylistic rather than editorial features as they composed their own narratives during writing workshops. Teachers, covering the key stage 2 age range (711), worked as research partners in nine schools. Over one year they observed and recorded each other during focused literacy sessions and writing workshops. The teachers attended preparatory and developmental meetings and met regularly to discuss progress.

\section{The literacy hour and writing workshops}

Although one hour each day was dedicated to literacy, the division of time, as shown in the NLS (1998) framework was not strictly adhered to and the term 'literacy sessions' was preferred. Teachers found that focusing, initially, on text level objectives was more effective than adhering rigidly to the National Literacy Strategy breakdown of the hour. In this respect our experience confirmed the conclusion, drawn by The 
Basic Skills Agency, that successful schools discard the clock and give priority to text level work (Frater, 2001). Teachers began focused literacy sessions by reading and discussing the impact of texts at an affective level and children investigated how authors had used language to achieve particular effects. The process of shared writing (DfEE 2000) was therefore, an important element of literacy sessions and, each week, a balance of reading and writing activity occurred. It was necessary to provide children with opportunities to work on sustained pieces of writing where they could apply new knowledge and skills in the context of, what Cairney and Langbien (1989) call, 'a writing community'. We considered writing workshops to be absolutely essential because they allow children to engage in authorial activity and experience writers' perspectives and readers' demands. We also wanted to develop a reciprocal scenario, where knowledge gained during focused literacy sessions fed into writing workshops and work produced in workshops looped back into literacy sessions. Our aim, during focused literacy sessions, was to examine texts written by 'expert' authors but also to discuss texts being produced by children themselves in writing workshops. During workshops children were given an opportunity to engage in sustained writing where they could gain continual feedback from response partners and teachers. The importance of linking the teaching of specific skills with opportunities to use them in genuine writing contexts is emphasised by the DfEE (2000: 19), which states that sentence level teaching 'can only improve children's writing if it genuinely and continually connects with real purposeful writing'. In its summary of the effective practice of writing at key stage 2 The Basic Skills Agency (Frater 2001: 13) stresses how successful schools 'ensured that extended time for extended writing was frequently and regularly available' and that at 'least an extra hour a week was found for writing in English'.

\section{Data base and analysis}

Teachers maintained research portfolios that provided baseline information about the school and children and included data collected over the focused research period (January-July 2001). Portfolios contained the following sections:

\section{Baseline information}

Baseline data was gathered from each school to provide information on academic achievement and contextual conditions.

\section{Record of teaching and learning activities}

Teachers' portfolios contained details of medium term plans and weekly and daily lesson plans for the research period. Work was planned with reference to the National Literacy Strategy framework (DfEE, 1998) and English in the National Curriculum (DfEE, 1999).

\section{Record of observations, reflections and evaluations}

Once a week, throughout the research period, teachers observed each other teaching a literacy session and writing workshop and kept logs that contained reflections and evaluations.

\section{Record of peer group discussions}

Discussions during group reading were audio-recorded to see if pupils were able to recognise the use of textual features by authors. Discussions were also examined for evidence of links between the metalinguistic awareness displayed by children during group reading and their own independent writing.

\section{Transcripts of teacher-pupil conferences}

Pupils' ability to discuss their work and justify the use of textual features was a crucial factor since this distinguished between Bereiter and Scardamalia's (1987) notion of knowledge telling and knowledge transformation. Transcripts of conferences allowed teachers to gain evidence of metacognitive development.

\section{Pupils' perspectives drawn from questionnaires and interviews}

Pupils completed questionnaires at the beginning and end of the research period. The questionnaires were designed to elicit information about how children felt about themselves as writers and to determine levels of self-esteem and confidence. On completion of sustained independent pieces of writing interviews were conducted to ascertain the extent to which children were making links between literacy sessions and writing workshops.

\section{Evaluation of pupils' written work}

A comparison was made between children's unaided written work before and after the research period. To evaluate the work of case study children a framework for analysing narrative writing was developed. In devising this we were influenced by the work of Paramour and Wilkinson (1985) who distinguish between chronicle, characterised by mundanity and predictability, to well-developed story, characterised by unpredictability and the disruption of probability. Major categories of structure, style and process were adopted from the National Literacy Strategy (Targets 
for Writing 2000). Although devised as a research tool the framework equated broadly to National Curriculum (1999) attainment targets for writing, e. g.

\begin{tabular}{|lc|}
\hline Framework for analysis & $\begin{array}{c}\text { National Curriculum } \\
\text { attainment targets }\end{array}$ \\
\hline 1 & $2 / 3$ \\
2 & $3 / 4$ \\
3 & $4 / 5$ \\
4 & $5 / 6$ \\
\hline
\end{tabular}

At the end of the research period, data from all schools was collated and a comparison was made between children's independent writing at the beginning and end of the research period. A total of 180 writing samples from 60 case study children (36 girls and 24 boys) were evaluated. Pupils' texts were marked first by the teachers and then separately by the project coordinator. In December (2000) pupils were producing narrative texts, largely at levels 1 and 2 on the framework, with a few beginning to show a limited number of structural and stylistic level 3 features in their work. In July (2001) pupils were functioning largely at levels 2 and 3, with some beginning to show structural and stylistic features of level 4 (tables 1 and 2).

The most significant development could be detected in the writing process, where children demonstrated an increased ability to critically evaluate and redraft their work (table 3).

At the beginning and end of the research period writing samples from all pupils were collected and analysed, using QCA (2001) test criteria to identify patterns of achievement in relation to National Curriculum levels of attainment. From a total of 338 children in the TRAWL project 16 children made no movement, 322 advanced at least one level, 128 children advanced two levels and six leapt three levels. In England, Key stage 2 pupils undertake Standard Assessment Tests (SATs) at the end of Year 6. The research group contained three year six classes: a top attainment set, a special needs set and a mixed ability class. The SAT results for writing in these classes are shown in table 4.

Although it is not possible to extrapolate, from such a small sample, pupils at both ends of the attainment spectrum appear to have made the greatest gains.

Table 1: Structural development in the writing of 60 case study pupils

\begin{tabular}{|c|c|c|c|c|c|}
\hline \multicolumn{3}{|l|}{ January 2001} & \multicolumn{3}{|c|}{ July 2001} \\
\hline Level 1 & 27 & & Level 1 & 0 & \\
\hline Level 2 & 33 & & Level 2 & 8 & \\
\hline Level 3 & 8 & showing some & Level 3 & 52 & \\
\hline & & & Level 4 & 19 & $\begin{array}{l}\text { showing some } \\
\text { features }\end{array}$ \\
\hline
\end{tabular}

Table 2: Stylistic development in the writing of 60 case study pupils

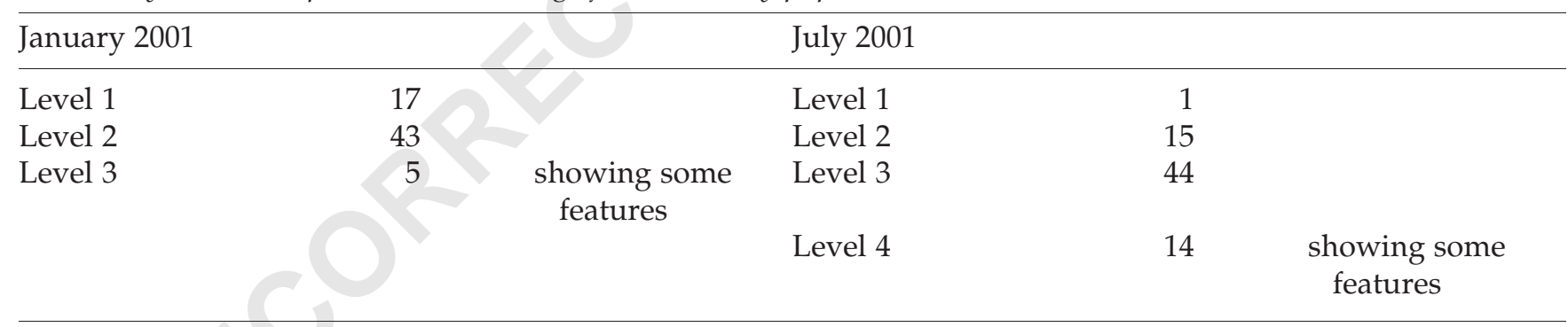

Table 3: Development in the writing process of 60 case study pupils

\begin{tabular}{|c|c|c|c|c|c|}
\hline January 2001 & & & July 2001 & & \\
\hline Level 1 & 37 & & Level 1 & 0 & \\
\hline Level 2 & 23 & & Level 2 & 26 & \\
\hline \multirow[t]{2}{*}{ Level 3} & 2 & $\begin{array}{l}\text { showing some } \\
\text { features }\end{array}$ & Level 3 & 34 & \\
\hline & & & Level 4 & 15 & $\begin{array}{l}\text { showing some } \\
\text { features }\end{array}$ \\
\hline
\end{tabular}


Challenging more able pupils is a current concern (QCA, 2001). The following example illustrates the development of one such child over the research period. Ashley was a very able year 6 pupil who was under achieving in independent writing tasks as exemplified by the following example (fig 1).

Commentary: Ashley [level 1 on the framework for analysis]

The story follows a linear chronicle of events but the logic is unclear. There is no character development and the motivation for characters' actions is not always clear. The vocabulary is simple and lacks variety. Few adjectives or adverbs are used and figurative language is not used to develop imagery, mood or suspense. The text is written in simple and compound sentences, and simple noun phrases are used. Sentences are demarcated but the text has no paragraphs and, although speech marks are in place, the dialogue is not appropriately laid out. A simple mindscape was made as a plan and minimal reference was made to this during composition. There was little re-reading of the text during composition and no changes were made to style, content or structure. There is little sense of reader and from a reader's perspective the story is unsatisfying.

The sample produced by Ashley in July (2001) is a very sophisticated piece of work that reflects his true talent (fig 2).

Commentary: Ashley [level 4 on the framework for analysis]

Table 4: Standard Assessment Test results in the three research schools with Year 6 classes

\begin{tabular}{|c|c|c|c|}
\hline & $\begin{array}{l}\text { Top attainment class } \\
\text { (27 pupils) }\end{array}$ & $\begin{array}{l}\text { Mixed attainment class } \\
\text { (34 pupils) }\end{array}$ & $\begin{array}{l}\text { Special needs class } \\
\text { (10 pupils) }\end{array}$ \\
\hline September 2000 & $\begin{array}{l}11 \text { level } 4 \\
16 \text { level } 3\end{array}$ & $\begin{array}{l}1 \text { level } 5 \\
15 \text { level } 4 \\
14 \text { level } 3 \\
4 \text { level } 2\end{array}$ & $\begin{array}{l}7 \text { level } 2 \\
3 \text { level } 1\end{array}$ \\
\hline SAT result & $\begin{array}{l}22 \text { level } 5 \\
5 \text { level } 4\end{array}$ & $\begin{array}{l}7 \text { level } 5 \\
20 \text { level } 4 \\
4 \text { level } 3 \\
3 \text { level } 2\end{array}$ & $\begin{array}{l}5 \text { level } 4 \\
5 \text { level } 3\end{array}$ \\
\hline Previous best SAT result & $\begin{array}{l}5 \text { level } 5 \\
20 \text { level } 4\end{array}$ & $\begin{array}{l}2 \text { level } 5 \\
13 \text { level } 4 \\
12 \text { level } 3 \\
5 \text { level } 2\end{array}$ & $\begin{array}{l}4 \text { level } 3 \\
7 \text { level } 2\end{array}$ \\
\hline
\end{tabular}

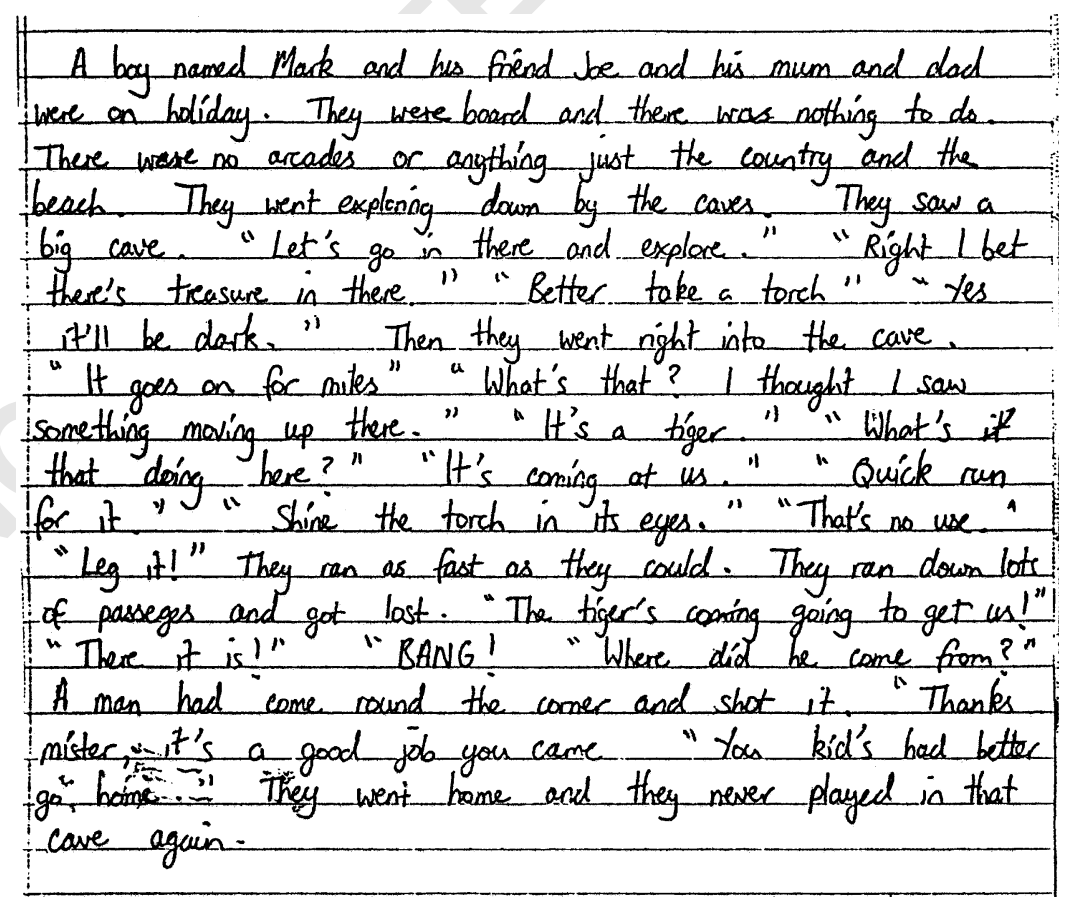

Figure 1. Ashley (Year 6) December 2000: assessed as level 1 on the framework 
The story is allegorical, concerned with issues of fear, evil, family ties, love and religious belief. There is intertextuality with reference to a psalm of David. Insights into characters are provided through various techniques, including thoughts, actions, mental state verbs and abstract nouns. Paragraphs are used to denote changes of scene or mood and the reader's attention is sustained through the use of narrative hooks. The overall narrative style is suitable for audience and purpose and a reader-writer relationship is established. Adjectives and verbs are chosen carefully for effect and the text is rich in figurative language. There is a deliberate patterning for emphasis and a conscious variety in sentence length and type. Adverbs or adverbial phrases are used to begin sentences and these are extended by the use of phrases and clauses. Punctuation is used for impact and grammatical conventions are broken for effect. Knowledge of different texts is drawn on and an appropriate style is chosen for the kind of story composed. During composition and significant changes were made to content, style and structure and there is a highly developed sense of readership.

\section{Metacognition}

Although test results and the general increase in attainment were pleasing our main concern was with developing children's metacognition, which we felt was essential for knowledge transfer and long term success. Bereiter and Scardamalia (1987) differentiate between knowledge telling where little planning, drafting, reflection or revision occurs, and knowledge transformation, which refers to a more dynamic process of writing where drafting and revision takes place and the writer is constantly reflecting on content, coherence, form and style. Conscious of Bereiter and Scardamalia's distinction, we looked for evidence of where children had made deliberate choices and could justify their decisions. The following extracts exemplify what we believe are examples of knowledge transformation.

After reading Sam's Duck by Michael Murpurgo, Jane (aged 8) has used his method of changing environments but has developed it with personification.

The rain covered motorway twisted and turned as it made itself into a churning road, the churning road changed itself into a weed covered lane, the weed covered lane wove itself into a misty field track.

The teacher asks:

$T \quad$ Why did you choose to do this?

$P \quad$ I wanted to kind of ... make it like it was...er ... alive with personification. It turned itself and then wove itself.
Having authorial authority means exerting the right not to use a device and in the following example Emma (aged 8) does just that. Rather than merely echoing Morpurgo's technique she has decided to use dialogue to mark a time shift.

Rhiane gazed out of the coach window while sadness ran up and down inside, where it hurt most. "HERE WE ARE CHILDREN" shouted Mrs Kingsly.

The teacher asks the child about her writing and she replies:

P I didn't really want to go on and on like Michael Murpurgo and I just wanted to get her there so I put the teacher shouting.

Development in the quality of children's writing and metacognitive awareness is exemplified by the work of Hannah (aged 8). In January 2000 her story structures resembled mere 'chains of events'. However, her metacognitive development and awareness of the reader has developed significantly by July 2001 (fig 3).

In her story Hannah depicts a character's thoughts and uncertainty by taking the reader inside the character's mind. Hannah explains her writing to the teacher during a writing conference

Hannah I've used streams of consciousness here. I've used ellipsis. I've got her thinking. I know characters aren't perfect. They have to think of things first. If you go inside a real person' head they don't go ...I will do this...I will do that.

The teacher asks Hannah what else she thinks she has done to make her writing interesting for the reader.

\begin{tabular}{|c|c|}
\hline Hannah & $\begin{array}{l}\text { These short sentences are like The Iron } \\
\text { Man. Ted Hughes says and then. Silence. } \\
\text { I've made up my own things. Footsteps. A } \\
\text { voice. Silence. They ... the readers don't } \\
\text { know whether it is good thing or a bad } \\
\text { thing coming. }\end{array}$ \\
\hline Teacher & $\begin{array}{l}\text { Yes are there any other devices you've used } \\
\text { to get an impact? }\end{array}$ \\
\hline Hannah & $\begin{array}{l}\text { (Reading from her text) Little did she } \\
\text { know something strange was going to } \\
\text { happen. Tonight at that very campsite. To } \\
\text { her. Even before they finish that sentence } \\
\text { they think, who to? To what? Is there } \\
\text { something going to hurt her? I've not } \\
\text { actually told them what is going to } \\
\text { happen ... but then I put To her and they } \\
\text { think wh-oh. }\end{array}$ \\
\hline
\end{tabular}



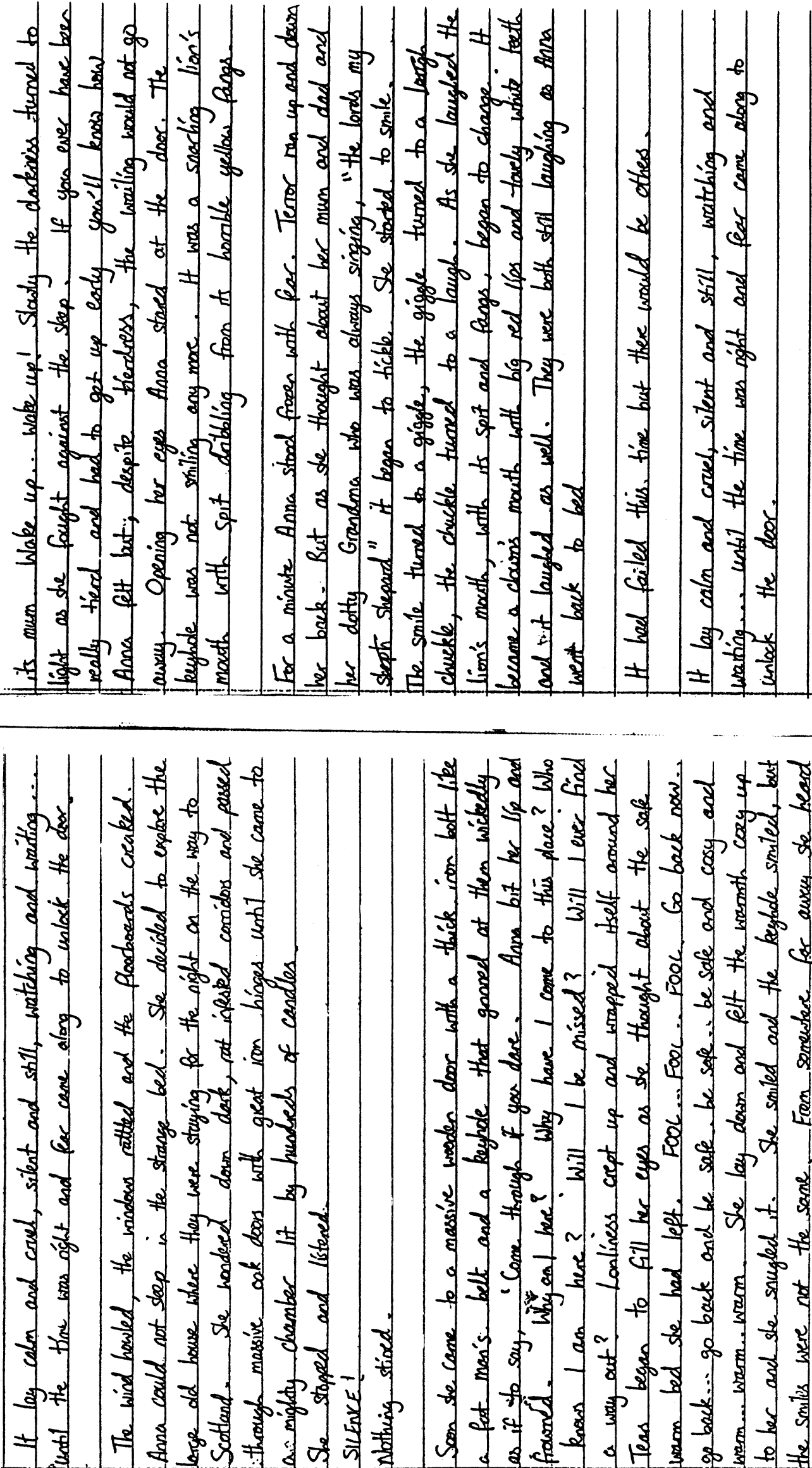

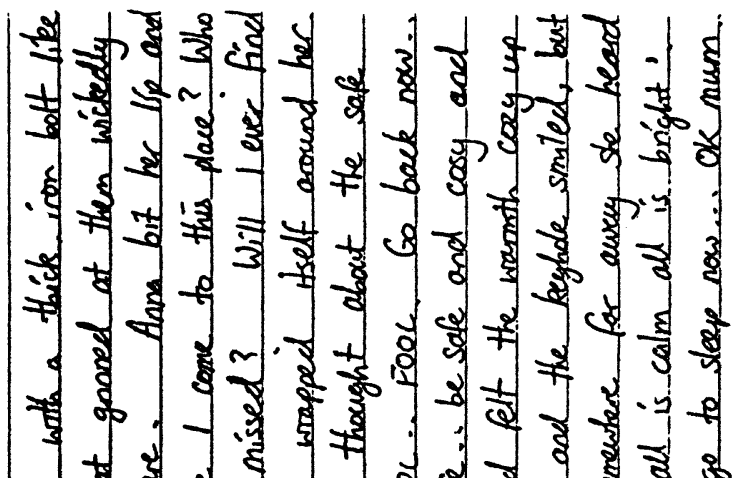

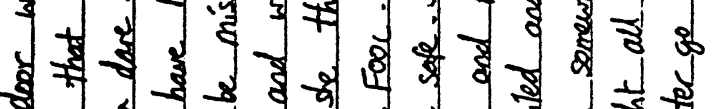

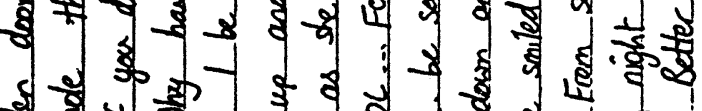

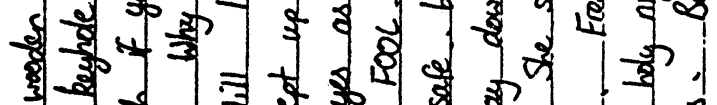

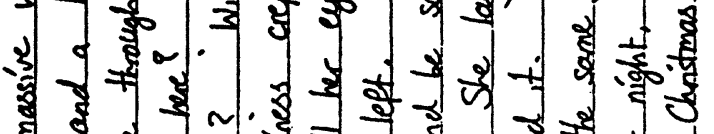
0,5 约

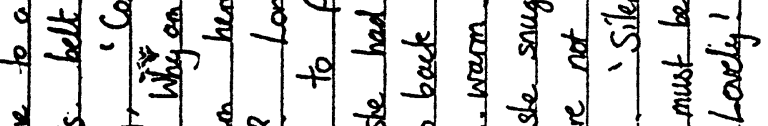

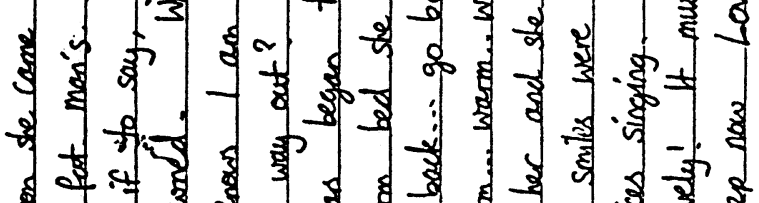

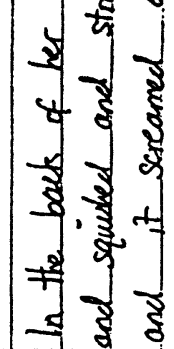




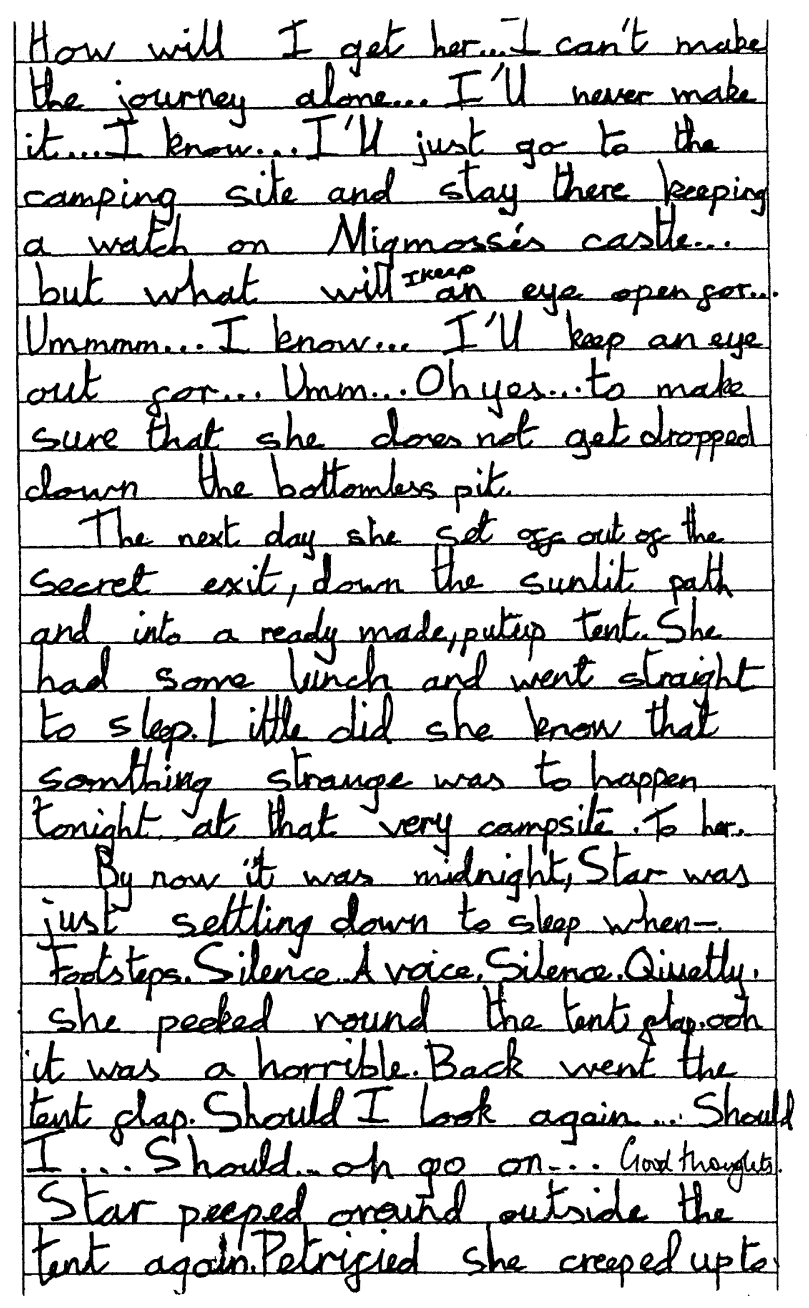

Figure 3. Hannah's work in July

\section{Conclusions}

With direction from teachers: providing models, demonstrating and drawing attention to the features of texts, and through focused group discussion, it appears that children can develop their awareness of how texts are constructed. An important aim of the TRAWL project was to develop children's confidence and raise their self-esteem as young authors. A disturbing feature to emerge from questionnaires and interviews, with children, was the high level of uncertainty that existed. Some children complained of feeling physically sick or being in mental agony when asked to write a story. Questionnaires, completed at the end of the research period, indicated a marked change. In the vast majority of cases anxiety and confusion had been replaced by confidence and enhanced self-esteem. Most children had developed strategic repertoires for writing and delighted in their ability to play with language and engage with readers.

One of the most striking features to emerge from our work was the way children gradually developed a metalanguage and were able to use it effectively when discussing their own texts. The use of specific literary terms helped children to clarify their thoughts, identify

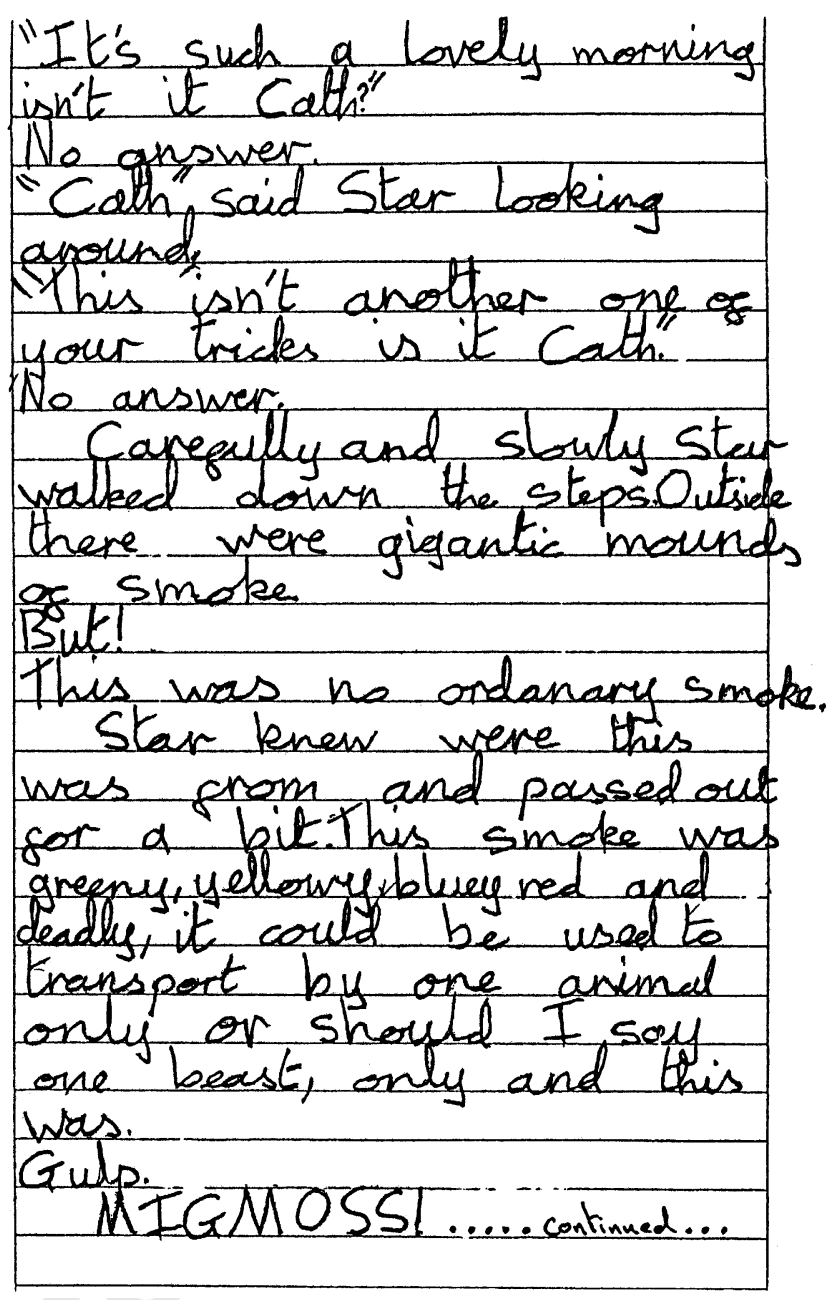

issues and engage in lucid, informed discussion. Through quality discourse with teachers and peers, children analysed texts proficiently and according to relevant criteria. They were then able to integrate the stylistic and organisational features of these texts into their personal repertoires and use them successfully in their own writing. This engagement in what Messenheimer and Packwood (2002) call deep, rather than surface, learning is crucial if children are to move beyond technically adept but formulaic writers to become autonomous creative authors.

\section{Issues and concerns}

Barrs and Cork (2001) show how young writers echo the styles and rhythms of texts that have been read aloud and explored through discussion and drama. TRAWL teachers also gained evidence of children using the stylistic features of texts and using literary devices that had been drawn to their attention during focused literacy sessions and writing workshops. One significant disadvantage of a prescriptive national literacy framework may be the marginalisation of role-play, visualisation and drama. Failure to include 
speaking and listening in the framework may have downgraded it in the eyes of many teachers, who feel themselves forced into an 'objectives coverage' approach to teaching that leaves little time for creative exploration and discussion. However, a more flexible approach to planning and teaching English in primary schools is beginning to emerge. The National Literacy Strategy and Local Eduaction Authorities are encouraging schools to plan work in extended blocks that provide time for sustained reading, writing, speaking and listening. There is a growing recognition that teaching for learning rather than for coverage means lessons based on selected text bytes and tightly controlled writing will not suffice. The work of Graham, Grainger and Lambirth (2002) demonstrates the importance of looking beyond the framework, drawing on children's knowledge and interest in popular culture and finding exciting ways of genuinely engaging young people with texts.

The gain in attainment by most pupils over a short period of time raises questions about general application and sustainability. Because 'pragmatic validity' was an important methodological concern, the TRAWL study took place in natural whole class settings and followed a common, reasonable timetable (see Frater 2001:14). The project involved a variety of teachers working in different contexts. Although rates of attainment varied, progress made by most pupils exceeded the national expectation. Some classes experienced substantial improvements and the possible reasons for this is something the project will focus on during its second phase (2001-2).

Teachers' subject knowledge emerged as a crucial factor in determining the quality of teaching and learning. Project teachers were aware of the development in their own understanding of how texts are crafted and the specific literary devices used by authors to create desired effects. Teachers also recognised how their knowledge influenced the quality of interaction with children during whole class or small group discussions. Perhaps, most importantly, they realised the importance of their own subject knowledge in enabling them to support young writers during composition. There are clear implications here for initial teacher education and continuing professional development.

Some concern has been raised over the explicit teaching of literary technique. There are fears that it will result in formulaic writing, where individuality and creativity are stifled and children lack any sense of ownership. For example, Graham (1998:117) describes teachers using 'counter-productive, mechanical tasks', whilst Gibbons (2001:16) advises against 'grafting technique on to none-too-willing children'. Hilton (2001: 8) is critical of the 'mechanical objectives-led approach' of the National Literacy Strategy (1998) and argues that the rigidity of the literacy hour, 'does not lend itself to sustained independent writing'. Teachers in the TRAWL project found, as did Lewis (1999), little evidence of children's creativity being stifled. On the contrary, as children developed their understanding of how texts are crafted they wrote with growing authority, drawing effectively on their strategic repertoires to orchestrate their writing. However, supporting young writers is a skilful business, which requires knowledgeable sensitive teachers. Care needs to be taken to ensure that scaffolding, rather than resulting in dependence, leads to independence and the creation of confident creative authors. Teachers need to assume a variety of teaching roles beyond that of 'expert' and subsequently, respond contingently to the needs of children as they discuss, plan, draft and re-draft written work (see Corden 1992 and 2001). Children need to experience what it is like to be an author: wrestling with problems, drawing on knowledge and experiences, seeking advice and responding to critical comments. Imaginative and resourceful teachers can create what Wells (1990) calls a community of literature thinking and what Cole (1995) refers to as a community of enquiry, where interactive discourse is central to the learning process. Graham (2001) has argued cogently for an approach to teaching writing which develops autonomy and she shows how reluctant writers can make significant progress when a culture of trust and respect exists in the classroom. TRAWL teachers will continue to offer structured support, during the second year of the project (2001-2002). They will also be looking more closely at the role of drama and visualisation as ways of enriching children's learning experiences and developing their love of literature.

\section{TRAWL project teachers}

Caroline Caille, Rosie Clark, Graham Cullen, Paula Dakin, Christina Dorn, Kate Fox, Suzanne Kirwin, Allison Long, Diana Mallows, Anne Murray, Andrew Ogden, Katherine Playford, Mark Scotton, Nikky Spice, Jayne Stevenson, Karen Taylor, Russell Tew, Elaine Welberry.

\section{Acknowledgements}

The TRAWL project is funded by The Nottingham Trent University and supported by a United Kingdom Reading Association (UKRA) research grant.

\section{References}

ALMOND, D. (2001) TTA Literacy Conference. London: September $12^{\text {th }}$.

BEREITER, C and SCARDAMALIA, M. (1987) The Psychology of Written Composition, Hilldale. New Jersey: Lawrence Erlbaum.

BARRS, M and CORK, V. (2001) The Reader in the Writer, London: CLPE.

CAIRNEY, T. and LANGBIEN, S. (1989) Building communities of readers and writers. The Reading Teacher, April. pp. 560-7. 
COLE, M (1995) Critical thinking, talk and a community of enquiry in the primary school. Language and Education 9 (3), pp 161-177.

CORDEN, R. (1992) 'The role of the teacher' in: K. NORMAN (Ed) Thinking Voices: the work of The National Oracy Project. London: Hodder and Stoughton.

CORDEN, R. (2001) Language and Literacy Through Talk, Buckingham: Open University Press.

DfEE (1998) The National Literacy Strategy Framework for teaching, Sudbury: DfEE.

DfEE (1999) The National Curriculum for English in England, London: DfEE/QCA.

DfEE (2000) Grammar for Writing, London: National Literacy Strategy/DfEE Publications.

DUFFIELD, J and PEACOCK, C. (1999) Teaching Writing. Final Report of Writing Audit to Falkirk Council Education Services, Research and Evaluation Service: Institute of Education, University of Sterling.

FRATER, G. (2001) Effective Practice in Writing at Key Stage 2, London: The Basic Skills Agency.

GIBBONS, A. (2001) Boy trouble. The Teacher, November, pp. 16-17.

GRAHAM, L. From Tyrannosaurus to Pokemon: autonomy in the teaching of writing. Reading literacy and language 35 (1), pp. 18-26.

GRAHAM, J. (1998) Teaching, learning and the National Literacy Strategy. Changing English 5 (2), pp. 115-121.

GRAHAM, L., GRAINGER, T. and LAMBIRTH, A. (2002) Symposium on Creative Writing, International Reading Association World Congress, July, Edinburgh.

HILTON, M. (2001) Writing process and progress: where do we go from here? English in Education 35 (1), pp. 4-15.

HMI (2000) Writing: could do better, HMI discussion paper. London: DfEE.

LEWIS, M. (1999) ‘Developing children's narrative writing using story structures' in: P. Goodwin The Literate Classroom, London: Fulton.
MESSENHEIMER, T. and PACKWOOD, A. (2002) Writing: the state of the state vs. the state of the art in English and American schools. Reading literacy and language 36 (1), pp. 11-15.

MORPURGO, M. (1996) Sam's Duck, London: Collins.

MURPURGO, M. (2001) In J. Carter, The Dream Weaver. Literacy and Learning Issue 20.

MYHILL, D. (2001) Better Writers, Suffolk: Courseware.

NATIONAL LITERACY STRATEGY (2000) Targets for Writing, Reading: NLS.

OFSTED (2000) The National Literacy Strategy: the second year, London: Ofsted.

OFSTED (2001) The National Literacy Strategy: the third year, London: Ofsted.

PARAMOUR, S. and WILKINSON, A. (1985) The description of the probable: an aspect of narrative writing 3-13. Language Arts 62 (4), pp. 91-403.

QCA (2001) English Tests Mark Schemes, London: Qualifications and Curriculum Authority.

QCA (2001) Working with gifted and talented pupils, Sudbury: QCA Publications.

STAINTHORP, R. (2002) Writing is hard. The Psychology of Education Review 26 (1), pp. 3-11.

WELLS, G. (1990) Creating the conditions to encourage literature thinking. Educational Leadership 47 (6), pp. 13-17.

CONTACT THE AUTHOR:

Roy Corden, Department of Primary Education, Ada Byron King Building, Clifton Lane, Nottingham, NG11 8NS 


\section{Author Query Form}

\section{Journal READ}

\section{Article $\quad 03701005$}

\section{Dear Author,}

During the copy-editing of your paper, the following queries arose. Please respond to these by marking up your proofs with the necessary changes/additions. Please write your answers on the query sheet if there is insufficient space on the page proofs. Please write clearly and follow the conventions shown on the attached corrections sheet. If returning the proof by fax do not write too close to the paper's edge. Please remember that illegible mark-ups may delay publication

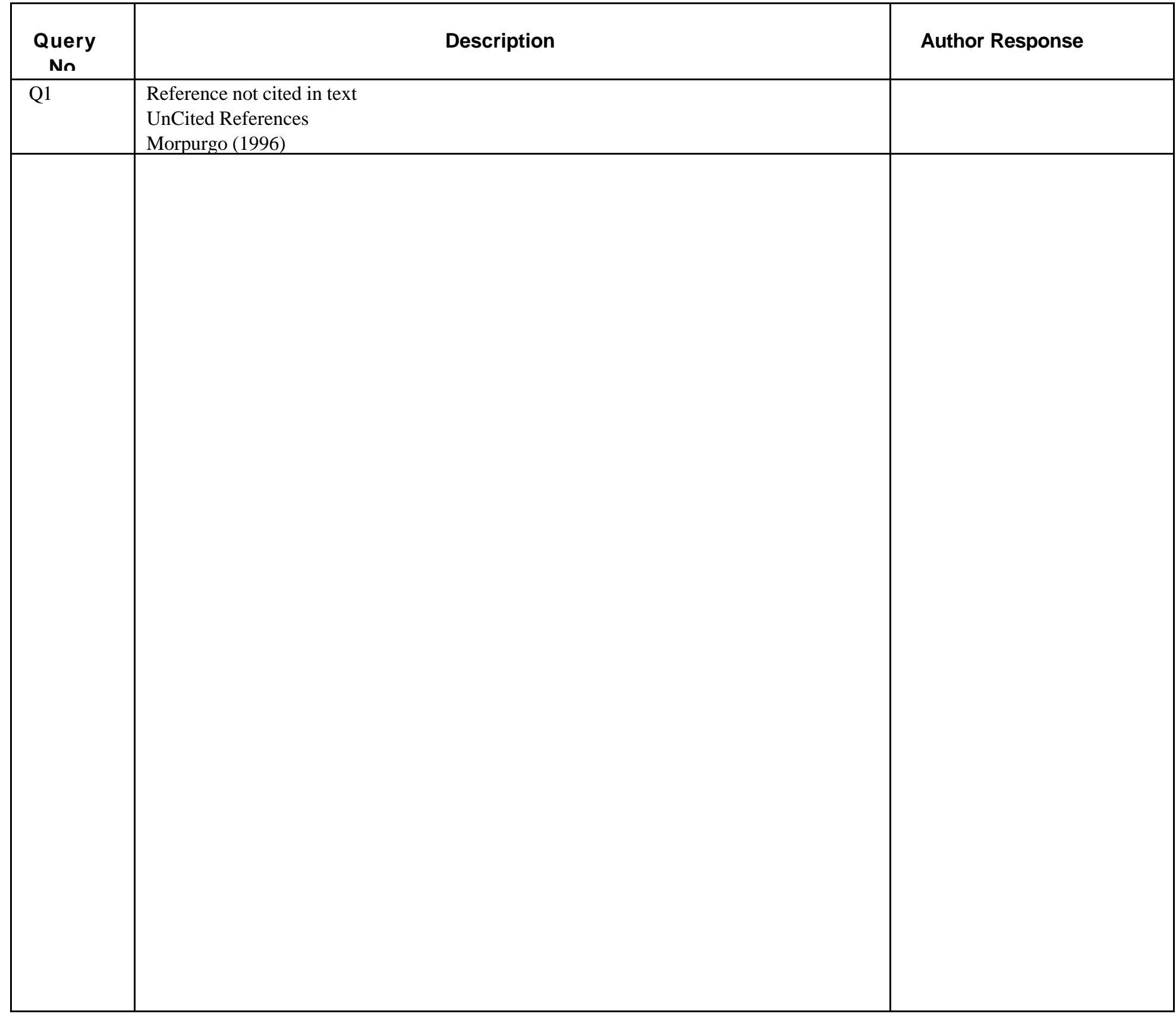

